\title{
Effects of School-Based Health Promotion on Adolescent Behavior in The Management of Obesity
}

\author{
Zahtamal ${ }^{1}$, Tuti Restuastuti ${ }^{2}$, Fifia Chandra ${ }^{3}$, Ridha Restila ${ }^{4}$ \\ \{afisifeizah@gmail.com.\} \\ ${ }^{1-4}$ Medical Faculty of Riau University, Indonesia
}

\begin{abstract}
Obesity is a problem that concerns all over the world continued to rise in adults, adolescents, and children. The study aims to figure out the effect of health promotion on the behavior of adolescents in managing obesity. This research was done using a quasi-experimental design with adolescents who are obese subjects. A selfReported questionnaire measured behavior. The data are analyzed using paired-samples t-test or Wilcoxon. The results showed that health promotion interventions had been able to increase the awareness, knowledge, attitude, subjective norm, self-efficacy, and intentions (in doing the physical level of activity) in the management of obese adolescents, both in physical exercise or the management of food intake. The schoolbased health promotion intervention has been able to improve the behavior of adolescents to obesity management.
\end{abstract}

Keywords: Obesity, physical activity, school-based health promotion, the role of schools.

\section{Introduction}

Obesity is defined as a disorder or a disease characterized by the accumulation of excessive body fat [1]. Obesity is a problem that concerns the world because its prevalence continues to increase in adults, adolescents, and children. Obesity in adolescents in developed and developing countries continues to increase from year to year [2]. The incidence of obesity in adolescents in Indonesia also increased. Some surveys conducted separately in some major cities indicate that the prevalence of obesity in adolescents is quite high [3][4].

Obesity has an impact on adolescent development, either of physical development (high risk of becoming obese in adulthood and the potential various chronic diseases and death and impaired psychosocial development). More specifically, obesity in adolescents in Asia-Pacific related to diabetes type 2 at a younger age [5].

Obesity in adolescents can't be ignored; more adolescents are obese today. It is an indication of health problems that will continue to develop in the adolescent. It is necessary to prevent and manage obesity in adolescents. Among the way is through the promotion of a healthy life, which includes physical activity and food intake regulation.

In fact, until now, health promotion to overcome obesity in adolescents has not been managed well and have not involved many parties. The responsibility to overcome health problems adolescents (students) majority/dominant only in the family. Changes in behavior also only focused on individual interventions (adolescents only), and without any effort comprehensive approach. Adolescents are considered as the object (less involved as agents of change) so that the problem of obesity in adolescents is not resolved. Lack of promotion will affect the obese, and the number will continue to increase. 
Since adolescents start in school, it is necessary to analyze the school contribution to prevent health problems, including obesity. Besides, schools also responsible for character building and attitude, as stated in Law on the National Education System (No. 20/2003). Schools have developed the ability, and character development/behavior and civilization of the nation's dignity to the intellectual life of the nation aims to the development potential of students to become healthy, knowledgeable, skilled, creative, and independent [6].

The effects of school-based health promotion on adolescents' behavior toward obesity had done by many researchers. The purpose of this study to reveal the effects of school-based health promotion in managing obesity in adolescents.

\section{Method}

This research uses a quasi-experimental method with one group pre and posttest design. It is conducted in high school (SMA) with a high number of students who have obesity in Pekanbaru city. There are two high schools sampled determined by quota sampling and conducted for six months (May to October).

Subjects in this study were obese with inclusion criteria: 1) youth with obesity (male or female), and 2) willing to be a participant. Furthermore, the exclusion criteria are; 1) suffering muscle and bone defects, 2) suffering heart disease, 3) asthma triggered by physical activity, 4) suffering serious illness requiring hospitalization, and 5) suffering or consuming drugs that affect body composition; such as Cushing syndrome, diabetes mellitus type-1, hypothyroidism. The participants are 20 teenagers with obesity for each group. During the data processing, four were invalid, so that the numbers of respondents are 36 people.

The instrument of this research measures with a tool (for conditions of obesity), and a self-reported questionnaire. Furthermore, the data is processed and analyzed quantitatively. Variable categories of awareness, knowledge, subjective norm, self-efficacy, intention, and family support are grouped into good (score 68-100), enough (score 34-67), and less (score 033). Especially for attitudinal variables, the category is positive (score 68-100), neutral (a score of 34-67, and negative (score 0-33). Testing the difference is done to assess the effectiveness of health promotion. The differential test used is the paired-t-test (if the data is normally distributed). If not, we used the Wilcoxon test with a significance value of $\mathrm{p}<0.05$. The intervention is done with the goal of behavioral change and improvement in obesity at youth. Methods of intervention can be seen in the matrix 1.

\begin{tabular}{|c|c|}
\hline $\begin{array}{l}\text { Intervention } \\
\text { Aspects }\end{array}$ & Method of Health promotion \\
\hline $\begin{array}{l}\text { Health } \\
\text { promotion } \\
\text { strategy }\end{array}$ & $\begin{array}{l}\text { Intervention in adolescents in the form of health education is done through } \\
\text { lectures Question and answer, accompanied by the media information about } \\
\text { the management of obesity (guide for physical exercise and diet regulation). } \\
\text { School-based health promotion activities implemented in schools that involve } \\
\text { elements of principals, teachers, and parents of teens. Lecture material } \\
\text { provided by the instructor (nutritionists, experts in the disease, and a team of } \\
\text { UKS school). This activity is done by sharing information, tips, and } \\
\text { experiences in the management of obesity, interactive discussions between } \\
\text { participants and instructors in the management of obesity. It aims to improve } \\
\text { the understanding and behavior of participants in the management of obesity. }\end{array}$ \\
\hline
\end{tabular}




\section{Result}

Based on the data processing to describe a category of participant awareness of physical exercise in the management of obesity before treatment is mostly good $(55.6 \%)$. After treatment, participants of awareness increase to be $86.1 \%$. The category of participant awareness related to food intake regulation, before treatment are mostly good $(50 \%)$, after treatment, the good category increased by $83.3 \%$.

Categories participants' knowledge of physical exercise in the management of obesity before treatment is mostly good $(52.8 \%)$. After the treatment, a category of knowledge participants increased to $61.1 \%$ good category. And also, participants' knowledge categories related to food intake regulation, before treatment are mostly good (75\%), after treatment, the good category increased by $88.9 \%$.

Furthermore, the attitude of participants performing physical exercises in the management of obesity before treatment is predominantly neutral $(55.6 \%)$. After the treatment, most of the participants' increased to $55.6 \%$. Likewise, The participant attitudes toward food before treatment was $19.4 \%$, and after treatment, it increased to $36.1 \%$. Overview subjective norm participant category for the management of obesity through physical exercise is known that before the treatment is mostly good $(77.8 \%)$, after treatment, the good category decreased to $63.9 \%$. The different results are shown by the subjective norm categories regarding participant's food intake regulation before treatment is mostly good $(63.9 \%)$, and after treatment, it increased to $75 \%$.

Based on the data processing also obtained a picture of self-efficacy category participants performs a physical exercise in the management of obesity. Before treatment, the good category was only $30.6 \%$ after treatment increased to $36.1 \%$. Likewise, self-efficacy participants performed categories of food intake regulation in the management of obesity, before treatment categories worth only $16.7 \%$ after treatment increased to $36.1 \%$. The results were not much different, also demonstrated by category intentions of the participants to do physical exercise in the management of obesity, before treatment is mostly sufficient $(94.4 \%)$, after treatment mostly turn out to be mostly good $(86.1 \%)$. Category intentions participants performed the food intake regulation in the management of obesity before treatment are mostly good $(86.1 \%)$ after treatment is still largely good, but there was a slight decrease to $80.6 \%$.

Furthermore, when seen from the different test results before and after the treatment is given in the form of school-based health promotion, known that, most of the increase in adolescent behavioral aspects in the management of obesity (Table 1 and 2). The results of the study to get an overview of difference variables adolescent behavior before and after the intervention (Table 1 and 2). 
Table 1. Different test variables behavior of physical exercise in the management of obesity before and after the intervention of health promotion

\begin{tabular}{llll}
\hline \multicolumn{1}{c}{ Variable } & $\begin{array}{l}\text { Observation 1 } \\
\text { Median and Min-Max }\end{array}$ & $\begin{array}{l}\text { Observation 2 } \\
\text { Median and Min-Max }\end{array}$ & P value \\
\hline Awareness & $70(20-100)$ & $90(30-100)$ & 0,003 \\
\hline Knowledge & $70(30-90)$ & $80(40-100)$ & 0,006 \\
\hline Behaviour & $60,6(45,45-78,79)$ & $66,6(42,42-87,8)$ & 0,050 \\
\hline Subejective norm & $72,2(33,3-88,89)$ & $66,6(33,3-88,89)$ & 0,992 \\
\hline Self efficacy & $50(25-83,33)$ & $50(19,44-75)$ & 0,394 \\
\hline Intention & $50(29,17-62,5)$ & $75(37,5-100)$ & 0,0005 \\
\hline
\end{tabular}

Table 2. Different test variables make arrangements food intake behavior in the management of obesity in the two study groups

\begin{tabular}{llll}
\hline Variable & $\begin{array}{l}\text { Observation 1 } \\
\text { Mean and standard } \\
\text { deviation/Median \& and Min- } \\
\text { Max }\end{array}$ & $\begin{array}{l}\text { Observation 2 } \\
\text { Mean and standard } \\
\text { deviation/Median \& and } \\
\text { Min-Max }\end{array}$ & P-value \\
\hline Awareness & $65(0-100)$ & $90(40-100)$ & $0,001^{\mathrm{b}}$ \\
\hline Knowledge & $66,67(33,3-91,67)$ & $83,3(41,67-100)$ & $0,001^{\mathrm{b}}$ \\
\hline Behaviour & $58,5 \pm 9,1$ & $61,02 \pm 10,89$ & $0,247^{\mathrm{a}}$ \\
\hline Subjective norm & $70,45(18,18-90,91)$ & $77,27(31,82-95,45)$ & $0,020^{\mathrm{b}}$ \\
\hline Selft efficacy & $50,67 \pm 14,22$ & $53,53 \pm 17,87$ & $0,402^{\mathrm{a}}$ \\
\hline Intention & $79,16(45,83-100)$ & $75(16,67-100)$ & $0,464^{\mathrm{b}}$ \\
\hline Note: & a) $=$ using paired samples T test & \\
& b) $=$ using the Wilcoxon test & &
\end{tabular}

Wilcoxon test for the behavior toward physical exercise in the management of obesity indicates a significant difference between before and after the intervention. Some variables show significant differences $(\mathrm{p}<0.05)$, including the awareness, knowledge, attitudes, and intentions, while subjective norms and self-efficacy showed no significant difference $(\mathrm{p}>$ 0.05). The different test variables make arrangements for food intake behavior in the management of obesity show a significant difference $(\mathrm{p}<0.05)$, including is the awareness, knowledge, and subjective norm. Meanwhile, attitudes, self-efficacy, and intention did not show differences significant $(\mathrm{p}>0.05)$.

\section{Discussion}

The results show that health promotion can increase awareness and knowledge of adolescents who are obese. It has previously been said by Zahtamal et al. [7] that the purpose of health promotion is to increase awareness and knowledge of a person. The application of health promotion models mainly using a variety of media and accurate methods to influencing and improving awareness of youth. Increasing awareness is the key fondation to improve 
adolescents' health quality. Teenagers who realize the importance of health programs will implement it wholeheartedly, without coercion, and felt that the program was their rights and obligations. Kahn et al. [8] and Zahtamal et al. [7] states that the purpose of health promotion is to increase a person's knowledge. MacKinnon et al. [9] also have proven health promotion influence on adolescent knowledge.

Health promotion interventions can also affect teenagers' behavior. The results showed a significant behavioral change in terms of the physical level of activity. With given health promotion showed an increase in their assessments of the aspect of the physical exercise. The different results occurred in their behavior in terms of regulating food intake. The results showed there had been a modest improvement in the mean score of behavior. However, it has not shown a significant influence. Many adolescent behaviors still in the neutral category. This behavior will have an impact on unhealthy eating behaviors that potentially could detain the management of obesity.

The results of this study indicate that health promotion has shown a good result in the improvement of the subjective norms in regulating food intake. The improvement of the subjective norm is certainly a positive thing for the formation of behavior, particularly for food regulation practice in managing obesity. One of the direct determinants of one's intention is the subjective norm related to the behavior. Subjective norm is determined by normative beliefs that others deemed important by the people agree or disagree on specific behaviors, which will affect the motivation to obey with the others [10]. In this study, the others are parents, friends, and teachers. The results of this study showed that given health promotion had not shown good results for the improvement of the subjective norm in physical exercise. It indicates the low confidence teens, particularly parents, can help or support them in doing physical exercise or be physically active.

The results showed that health promotion is not strong enough to increase self-efficacy. It is recognized that it is not easy to change or actualize self-efficacy for the better. It is because a lot of things play a role in the formation of self-efficacy. Self-efficacy is a person's belief in its ability to organize and carry out a series of actions required to manage prospective situations. Self-efficacy does not simply know what is supposed to do. To carry out a skilled performance, people need to have the necessary skill and self-confidence in their ability to use that skill. Someone with high self-efficacy will be more successful in completing its tasks than those who have low self-efficacy [11].

In the management of obesity, several things must be accurately and consistently made within a relatively long time, including physical exercise activity, readiness, and availability of food, food process with appropriate diet, and time management skills. In addition, the ability to anticipate their personal and environmental obstacles in actualizing healthy behavior. Related to the behavior application in the long term until it becomes a habit, efficacy beliefs also determine the amount of effort that must be done, and the duration peoples can survive to face failure and adversity. Strong beliefs about self-efficacy can strengthen resilience when facing a difficult task. In addition, efficacy beliefs influence the thoughts and feelings of the people. The person who sees he have no efficacy to face environmental demands tends to exaggerate his deficiency, become easily discouraged, and give up when facing difficulties. Conversely, the person who has strong beliefs that have efficacy, although they may be down temporarily when encounter failure but will tend to keep thinking about the task and will expand its effort if its performance almost reaches goals. In the struggle that requires determination, belief in self-efficacy plays an important role. The results of other studies proved that there is an effective health promotion to self-efficacy. At this time, self-efficacy has been cited as influencing variables identified various changes in behavior as well as fruit 
and vegetable consumption in adults [12]. Self-efficacy is also reported to be a strong predictor consistently to make someone physically active [13].

Based on this research, health promotion known to be strong enough to improve intense physical activity in adolescents, which is the best predictor of behavior. To know what will be done by someone, the best way to predict it is to know the intensity. Ajzen [14] defines intensity as the position of the subject on the dimensions of subjective probability accompanying the relation between himself and an action. Intensity is determined by behavior, subjective norm, and other behavioral attributes. Intensity is an intention to try to show that it is certain, the closest cause of the occurrence of visible behaviors. Intensity to regulate the behavior at the time and the right opportunity will turn it into action.

\section{Conclusion}

School-based health promotion interventions effective in increasing awareness, knowledge, behavior, and intensity, as well as for subjective norm and self-efficacy, but the effect is not strong enough. Furthermore, school-based health promotion is also effective in increasing awareness, knowledge, and subjective norm in the regulation of food intake.

\section{References}

[1] World Health Organization. Obesity. Preventing and managing the global epidemic. Report of a WHO consultation (Geneva: WHO). (2000)

[2] Fryar, Cheryl D, Margaret D. Carroll and Cynthia L. Ogden. Prevalence of Obesity Among Children and Adolescents: United States, Trends 1963-1965 Through 20092010. Division of Health and Nutrition Examination Surveys, National Center for Health Statistics, Washington, DC. http://www.cdc.gov/nchs/data/hestat/obesitychild09 10/obesity_child_09 10.pdf. (2012)

[3] Padmiari, IAE, Hadi H. Konsumsi Fast food Sebagai Faktor Risiko Obesitas pada Anak Sekolah Dasar. Medika, 29 (3): 159-165. (2000)

[4] Badan Pusat Statistik (BPS). Survey Sosial Ekonomi Nasional (Susenas) Tahun 2004: Jakarta: Badan Penelitian dan Pengembangan Kesehatan. (2005)

[5] Mahoney LT, Bums TL, Stanford, W, Thompson BH, Witt JD, Rost CA., Lauer RM. Coronary risk factors measured in childhood and young adult life are associated with coronary artery calcification in young adults: the Muscatine Study. J Am Coll Cardiol; 27:277-284. (1996)

[6] Sekretaris Negara Republik Indonesia. Undang-Undang Republik Indonesia Nomor 20 Tahun 2003 tentang sistem pendidikan nasional. Jakarta: Mensesneg RI. (2003)

[7] Zahtamal, Rochmah W, Prabandari YS, Setyawati LK. Pengaruh Promosi Kesehatan di Tempat Kerja Secara Multilevel terhadap Perilaku Pekerja dengan Sindroma Metabolik. Buletin Penelitian Kesehatan, 2015, 43 (3) (6); 173-182 (2015)

[8] Kahn, EB, Ramsey LT, Brownson RC, Heath GW, Howze EH, Powell KE, Stone EJ, Rajab, M.W., Corso, P. The effectiveness of interventions to increase physical activity. Am J Prev Med, 22 (4S): 73-108. (2002) 
[9] MacKinnon DP, Elliot D., Thoemmes F, Kuehl KS, Moe EL, Goldberg L, Burrell GL, Ranby KW. Long-term Effects of a Worksite Health Promotion Program for Firefighters. Am J Health Behav, 34(6): 695-706. (2010)

[10] Achmat Z. Theory of planned behavior, masihkah relevan?. Available on: http://zakarija.staff.umm.ac.id/files/2010/12/Theory-of-Planned-Behavior-masihkahrelevan1 .pdf.[Downloaded on Mei 20th2012]. (2010)

[11] Syahrul. Analisis model struktural kematangan vokasional mahasiswa program D-3 Teknik Elektro Fakultas Teknik UNM. Jurnal MEDTEK, 3 (2): 1-11. (2011)

[12] Baranowski T, Cullen KW, Baranowski J. Psychosocial correlates of dietary intake: Advancing dietary intervention. Annual Review of Nutrition, 19: 17-40. (1999)

[13] Sherwood NE, Jeffery RW. 2000. The behavioral determinants of exercise: Implications for physical activity interventions. Annual Review of Nutrition, 20: 21-44.

[14] Ajzen I. Attitudes, Personality, And Behavior. Second Edition. New York: Open University Press. (2005) 